\title{
Taxonomic notes on Poecillastra sponges (Astrophorida: Pachastrellidae), with the description of three new bathyal southeastern Pacific species
}

\author{
MARIANA S. CARVALHO ${ }^{1}$, RUTH DESQUEYROUX-FAÚNDEZ ${ }^{2}$ \\ and EDUARDO HAJDU ${ }^{1}$ \\ ${ }^{1}$ Museu Nacional, Departamento de Invertebrados, Universidade Federal do Rio de Janeiro, Quinta da Boa Vista, s/n, \\ 20940-040, Rio de Janeiro, RJ, Brazil. E-mail: mscarv@ gmail.com \\ ${ }^{2}$ Museum d'histoire Naturelle, P.O. Box 6434, 1211 Geneva 6, Switzerland.
}

\begin{abstract}
SUMMARY: Three new species of Poecillastra are described here from bathyal waters off central Chile. P. antonbruunae n. sp. is diagnosed by its two categories of oxeas, the smaller one only up to $621 \mu \mathrm{m}$ in length, and calthrops as the sole triaene category; $P$. sinetridens $\mathrm{n}$. sp. by the possession of oxeas larger than $3000 \mu \mathrm{m}$ long, microxeas which can be over $300 \mu \mathrm{m}$ long, and absence of triaenes; and P. maremontana n. sp. by its three categories of oxeas, three categories of streptasters (one of spirasters and two of plesiasters), one category of calthrops and centrotylote microxeas. Comments upon other Poecillastra and an identification key for Pacific species of the genus are given. Evolutionary hypotheses are discussed for the genus given the distribution of spicule morphotypes, as well as the recurrent phenomenon of spicule loss in Astrophorida. Five species of Pachastrella are transferred here to Poecillastra on the basis of their possession of microxeas instead of microrhabds, viz. P. cribrum Lebwohl, 1914; P. dilifera de Laubenfels, 1934 [sensu Dickinson (1945)]; P. fusca Lebwohl, 1914; P. incrustata Bergquist, 1968; and P. scrobiculosa Lebwohl, 1914. We recognize 28 species of Poecillastra, 19 of them occurring in the Pacific Ocean.
\end{abstract}

Keywords: taxonomy, Porifera, Demospongiae, Chile, Pacific Ocean, bathyal waters.

RESUMEN: Taxonomía de esponjas Poecillastra (Astrophorida: Pachastrellidae), con la descripción de tres nuevas especies batiales del Pacífico suroriental. - El presente trabajo describe tres nuevas especies de Porifera del género Poecillastra, de aguas profundas de la región central de Chile. $P$. antonbruunae $\mathrm{n}$. sp. presenta dos categorías de oxeas, la más pequeña solo hasta $621 \mu \mathrm{m}$ de longitud y calthrops como la categoría única de trienios; $P$. sinetridens n. sp. posee oxeas de tamaño superior a $3000 \mu \mathrm{m}$ de longitud, sus microxeas alcanzan un tamaño superior a $300 \mu \mathrm{m}$ de longitud y los trienios están ausentes. P. maremontana n. sp. posee tres categorías de oxeas y tres de streptasters (una de spirasters y dos de plesiasters). Posee además una sola categoría de calthrops y microxeas centrotylotadas. En el presente trabajo se incluyen comentarios acerca de otras especies de Poecillastra, así como una clave de identificación del género para las especies del Pacífico. Se discuten también hipótesis evolutivas del género, basadas sobre la distribución de sus diferentes morfotipos espiculares, así como el fenómeno recurrente de la pérdida de espículas en el orden Astrophorida. Cinco especies del género Pachastrella fueron transferidas para Poecillastra en consecuencia de poseer micróxeas en vez de microrabdos, viz. P. cribrum Lebwohl, 1914; P. dilifera de Laubenfels de 1934 [sensu Dickinson (1945)]; P. fusca Lebwohl, 1914; P. incrustata Bergquist, 1968; y $P$. scrobiculosa Lebwohl de 1914. Actualmente consideramos válidas 28 especies de Poecillastra, 19 de ellas ocurren en el Océano Pacífico.

Palabras clave: taxonomía, Porifera, Demospongiae, Chile, Océano Pacífico, aguas profundas.

\section{INTRODUCTION}

The order Astrophorida Sollas, 1888 is characterized by possession of triaenes and oxeas as main megas- cleres, although the absence and rarity of the former is common in Ancorinidae Schmidt, 1870 (Jaspis Gray, 1867; Holoxea Topsent, 1892; Melophlus Thiele, 1899; Rhabdastrella Thiele, 1903 and Asteropus Sol- 
las, 1888; Uriz, 2002). In Pachastrellidae Carter, 1875, tetraxons are a widespread character, and their absence is described here for the first time.

Poecillastra Sollas, 1888 is diagnosed as Pachastrellidae with calthrops and/or other kinds of shortshafted triaenes as megascleres, and microscleres which are microxeas and several types of streptasters (Maldonado, 2002). According to van Soest et al. (2008), 23 species are known, 9 of which were reported from the Pacific Ocean, viz. P. ciliata Wilson, 1925 (Philippines); P. compressa (Bowerbank, 1866) sensu Sollas (1888; Queen Charlote Islands); P. cribraria Wilson, 1904 (Galapagos); P. japonica (Thile, 1905; Japan); P. laminaris (Sollas, 1886; New Caledonia); P. rickettsi de Laubenfels, 1930 (California, USA); P. stipitata Lévi, 1993 (New Caledonia); $P$. tenuilaminaris (Sollas, 1886; California, USA and Japan); and P. wondoensis Sim and Kim, 1995 (Korea). Most appear to be from relatively deep waters. Other areas such as the Atlantic Ocean and Mediterranean, with five species each, and the Indian Ocean, with three species, are poorer or so far have been less thoroughly investigated.

Pachastrellidae is an important source of new bioactive molecules of potential commercial value, such as Dercitine, from Dercitus sp., with a marked antitumoral activity (Burres et al., 1989); Psammapline A, from Poecillastra sp., with antibacterial activity (Kim et al., 1999); and a citotoxin from Pachastrella sp. (Gunawardana et al., 1989). Nevertheless, the relatively small numbers of species known from several large basins and the deep-sea dwelling habit of many species suggest that there is a need for improved taxonomic effort.

Six species of Astrophorida were previously known from Chile, viz. Asteropus ketostea (de Laubenfels, 1950), Asteropus simplex (Carter, 1879), Geodia amphistrongyla Lendenfeld, 1910, Geodia magellani (Sollas, 1886), Stelletta phrissens Sollas, 1886, and Stelletta vosmaeri (Sollas, 1886). In the present study we describe three new species of Poecillastra from central Chile $\left(32^{\circ} \mathrm{S}-35^{\circ} \mathrm{S}\right)$. One of these species is atypical in lacking triaenes. This study further determines the status of the Pacific Ocean as the richest ocean basin for this genus. A brief review of Poecillastra species worldwide is undertaken, comparing them to the new species described here, and possible biogeographic scenarios are outlined taking into account the distribution of spicule morphotypes within the genus and their primary suggestion of monophyly of the species group sharing these characters.

\section{MATERIALS AND METHODS}

Specimens were collected off the central Chilean coast from 290 to $450 \mathrm{~m}$ depth. Figure 1 illustrates the collecting localities for the three specimens studied. These were collected by distinct oceanographic/ fisheries surveys, and were deposited in the following

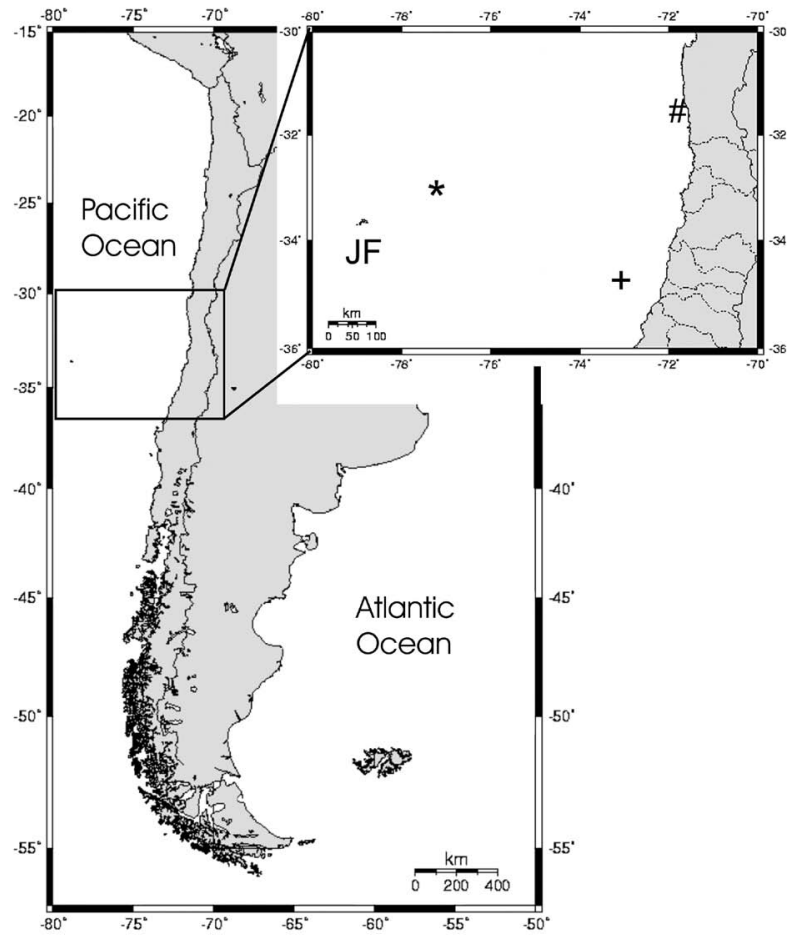

FIG. 1. - Map of the Chilean coast highlighting its central portion and the location of each new species's type locality. \#, Poecillastra antonbruunae n. sp. (off Constitución); *, P. maremontana $\mathrm{n}$. sp. (off Juan Fernandez Archipelago); and,$+ P$. sinetridens n. sp. (off Zapallar, Valparaiso). JF, Juan Fernandez Archipelago.

institutions: United States National Museum (USNM, Washington, D.C., USA), Museum d'Histoire Naturelle (MHNG, Geneva, Switzerland), and the Huinay Scientific Field Station (HSFS, Huinay, Chile).

Procedures for the study of spicules and skeletal architecture under light microscopy and scanning electron microscopy (SEM) followed Hajdu (1994). SEM analysis was carried out at the Instituto de Biofísica Carlos Chagas Filho and the Museu Nacional, both at the Universidade Federal do Rio de Janeiro, Brazil.

Twenty spicules of each category for each specimen were randomly selected and measured, except for oxeas (50 measurements) or in cases in which more measurements were necessary to precisely establish size ranges for the other spicule types. An exhaustive search for maximum and minimum ranges was done. Spicule dimensions are presented as minimum-mean-maximum length and width, in micrometres.

Abbreviations: MHNG, Museum d'Histoire Naturelle, Geneva; MNRJ, Museu Nacional, Rio de Janeiro; BMNH, Natural History Museum, London; SEPBOP, South-East Pacific Biological Oceanographic Program; SOSC, Smithsonian Oceanographic Sorting Centre; ZMAPOR, Zoological Museum of the University of Amsterdam, Porifera collection; ZIL, Zoological Institute of the Russian Academy of Sciences, St. Petersburg. 


\section{SYSTEMATICS}

Class Demospongiae Sollas, 1885

Order Astrophorida Sollas, 1888

Family PaChastrellidae Carter, 1875

Genus Poecillastra Sollas, 1888

Definition. Pachastrellidae, whose microscleres always include streptasters in the form of spirasters and plesiasters, as well as microxeas in a single category (Maldonado, 2002).

Type species. Poecillastra compressa (Bowerbank, 1866: 55) (by original designation).

\section{Poecillastra antonbruunae n. sp.}

(Fig. 2, Table 1)

Type material: Holotype Chile: USNM 1109999; off Constitución (SEPBOP Expedition station 18A 697, 35⒉' 'S 7301' 'W), 290-450 $\mathrm{m}$ depth, coll. ‘Anton Bruun' (SOSC), 09/viii/1966. Schizotypes MNRJ 9645, ZMAPOR 14932.

Comparative material. Poecillastra eccentrica Dendy and Burton, 1926 (BMNH 1926.10.1.95, holotype).

Diagnosis. Poecillastra with two categories of oxeas, the smaller one only up to $621 \mu \mathrm{m}$ in length.

Description. The single known specimen is lamellate, $0.4 \mathrm{~cm}$ high, and $6 \times 5.2 \mathrm{~cm}$ in diameter (Fig. 2A). Both surfaces are rough to the touch, hispid, with projecting oxeas ( $c a .1000 \mu \mathrm{m}$ beyond the surface), and with a great number of pores that seem to be oscules $(0.5-1 \mathrm{~mm}$ in diameter) on one side, while the other side has fewer pores. The sponge is firm and incompressible. Colour is dark beige in ethanol.

Skeleton: Ectosomal skeleton is composed of abundant spirasters and microxeas, but also contains oxeas and calthrops. The smaller oxeas are principally present in the ectosome, although not forming a crust. Choanosomal skeleton confused and crossed by aquiferous channels, with oxeas and calthrops more abundant than in the ectosome.

Spicules (Fig. 2B-H): Megascleres are oxeas in two categories and calthrops. Oxeas I slightly curved, with acerate tips sharpening gradually, 972-1924.2-3060 $\mu \mathrm{m}$ long and 14-36.9-53 $\mu \mathrm{m}$ thick. Oxeas II (mostly ectosomal) smooth, slightly curved, 262-401.6-621 $\mu \mathrm{m}$ long and 10-14.6-24 $\mu \mathrm{m}$ thick. Calthrops, mostly equiangulated, with equal rays, actines 242-423.4-572 $\mu \mathrm{m}$ long and 17-27.4-36 $\mu \mathrm{m}$ thick. Microscleres are spirasters 15-17.7-24 $\mu \mathrm{m}$ long; and acanthomicroxeas, straight or occasionally slightly curved, 73-99.9-136 $\mu \mathrm{m}$ long and 4-4.6-6 $\mu \mathrm{m}$ thick.

Etymology. The new species name "antonbruunae" is in honour of the ship "Anton Bruun", whose crew collected this species. We opted for female gender termination as ships are usually referred to as "she".
Distribution. Known only from its type locality, off Constitución, central Chile.

Remarks. The new species is closely related to Poecillastra schulzei (Sollas, 1886, sensu Sollas, 1888) in its spicule composition (see Table 1). Nevertheless, the status of $P$. schulzei and its alleged synonyms has been the subject of a long debate, still in need of some clarification. Poecillastra schulzei was considered to be conspecific with $P$. compressa (Bowerbank, 1866) by some authors (Topsent, 1894; Burton, 1930). Recently, however, Maldonado (2002) re-examined the type of the former and determined its validity on the basis of the possession of two categories of oxeas, as opposed to only a single category in $P$. compressa. Poecillastra tenuilaminaris, suggested by Burton (1959) to be a likely synonym of $P$. schulzei, has been considered a valid species by Maldonado (2002) on the basis of its lack of slender ectosomal oxeas. According to Maldonado, Poecillastra schulzei is an Indo-Pacific/Southern Ocean species (but see below), and P. tenuilaminaris is a North Pacific one.

Poecillastra laminaris (Sollas, 1886) and P. eccentrica Dendy and Burton, 1926, from the Indo-Pacific region, were also regarded as possible junior synonyms of P. schulzei by Maldonado (2002). The proposed likely synonymy of tropical species of Poecillastra, $P$. eccentrica and $P$. laminaris with the originally subantarctic $P$. schulzei, though supported by re-examination of the relevant type material (Maldonado, 2002), implies accepting a considerable morphologic variability and a marked eurybathyal distribution in the concept of "P. schulzei". Poecillastra eccentrica was originally reported with much larger calthrops, a varied set of triaenes, smaller asters, and completely lacking rough microxeas (Dendy and Burton, 1926). Maldonado (2002) had the opportunity to examine microscopic preparations of this species, but unfortunately provided very few arguments to support this proposed synonymy. Re-examination of the holotype of P. eccentrica (BMNH 1926.10.1.95; two spicule slides and two thick section slides) revealed the presence of microxeas as well as larger oxeas, both overlooked by Dendy and Burton (1926). We concluded from the confirmed presence of relatively larger calthrops that $P$. eccentrica is a valid species. Conversely, P. laminaris was originally described with trichoxeas representing a second category of much larger and slender oxeas, a trait not present in $P$. schulzei. Additionally, $P$. laminaris possesses relatively smaller asters, and occurs in a much deeper and more distant habitat. Consequently, this proposed synonymy should also be verified through re-examination of type material, which has not been possible here. We consider $P$. schulzei to be a subantarctic species, characterized by possession of two categories of oxeas rather well differentiated in terms of length and thickness (Table 1), triaenes in two forms (larger orthotriaenes and smaller calthrops), microxea, metasters and spirasters. It ap- 

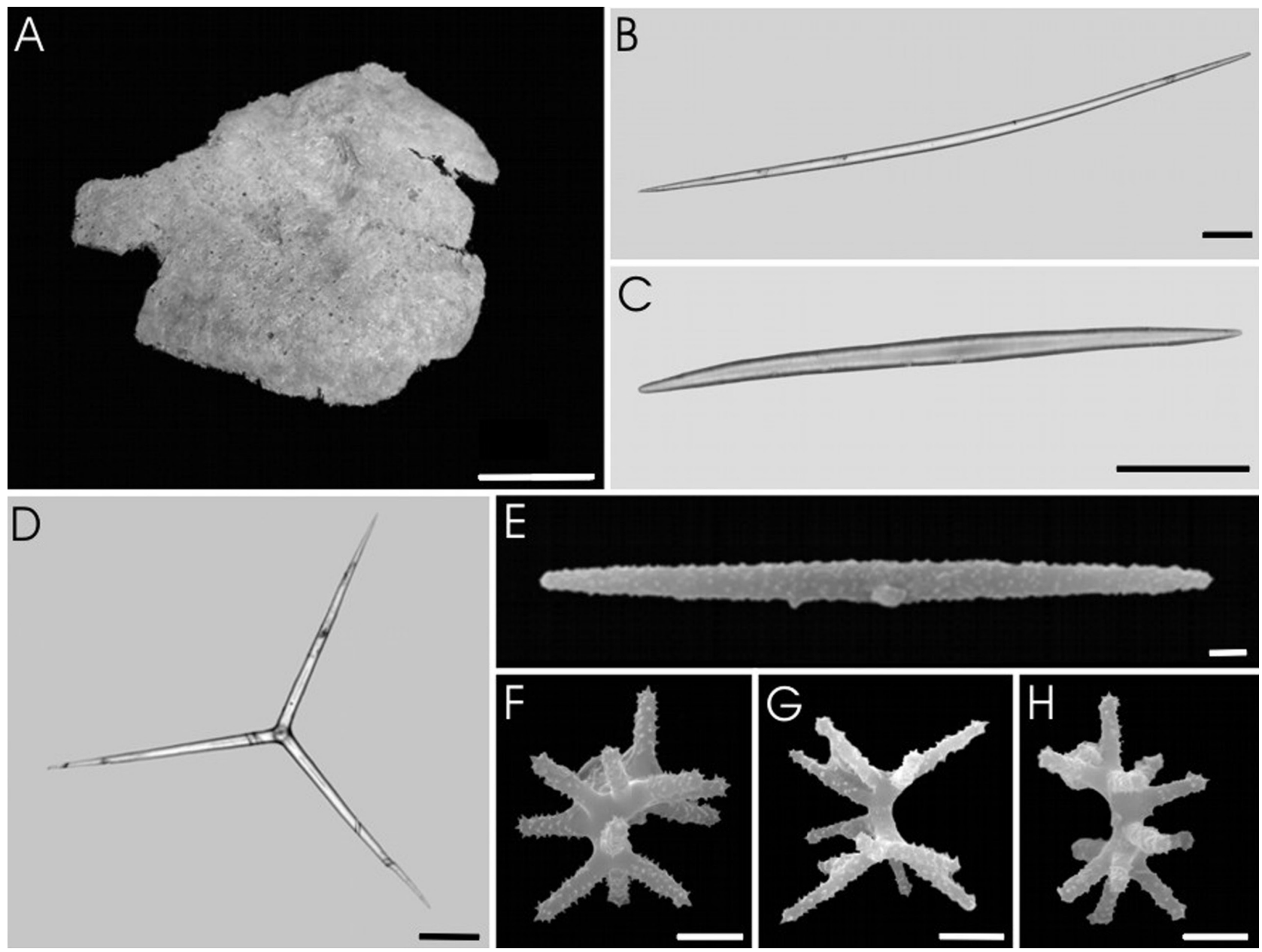

FIG. 2. - Poecillastra antonbruunae n. sp. A, schizotype (MNRJ 9645). B, Oxea I. C, Oxea II. D, Calthrops. E, Acanthomicroxea. F-H, Spirasters. Scale: A, $1 \mathrm{~cm}$; B-D, $100 \mu \mathrm{m} ; \mathrm{E}-\mathrm{H}, 5 \mu \mathrm{m}$.

proaches the new species as both possess two categories of oxeas and calthrops as megascleres, as well as spirasters as microscleres. However, they differ in the presence of orthotriaenes and metasters in P. schulzei. Additionally, oxeas I in the new species are slightly smaller and thinner.

None of the alleged synonyms of $P$. schulzei cited above approaches our new species as closely as Sollas's original material. The other new species described from this region are discussed further below.

\section{Poecillastra maremontana n. sp.} (Fig. 3, Table 1)

Type material. Holotype, Chile: IZUAPOR-0130; Juan Fernandez 2 seamount $\left(33^{\circ} 36^{\prime} 37.2^{\prime \prime S} 77^{\circ} 41^{\prime} 46.2^{\prime \prime W}\right.$, Juan Fernandez Archipelago), 338-414 m depth, coll. R. Vega ('Portugal II'), 27/vii/2007. Schizotype MNRJ 12563.

Diagnosis. Poecillastra with three categories of oxeas, three categories of streptasters (one of spirasters and two of plesiasters), one category of calthrops and centrotylote microxeas.
Description. The single known specimen is lamellate and consists of fragments (Fig. 3A), the largest one $7 \times 4.7 \times 0.5 \mathrm{~cm}$ (height $\times$ length $\times$ thickness). The surface is hispid with several scattered oscules (up to $1.5 \mathrm{~mm}$ in diameter). These oscules are more visible on one side of the sponge than the other. The colour is white in ethanol.

Skeleton: Ectosomal skeleton has no specialization, apart from a dense concentration of all microscleres around the pores. Choanosomal skeleton confused with scattered oxeas I, II and III. Calthrops, plesiasters, and spirasters are scattered through the ectosome and choanosome.

Spicules (Fig. 3B-J): Megascleres are oxeas in three categories and calthrops. Oxeas I, slightly curved, mostly with acerate tips (rarely with one or both tips rounded), 1516-3432 $\mu \mathrm{m}$ in length and 24-42.2-54 $\mu \mathrm{m}$ in width. Oxeas II, slightly curved, mostly with acerate tips (rarely with one or both tips rounded), 315-1401 $\mu \mathrm{m}$ in length and 10-21.6-34 $\mu \mathrm{m}$ in width (oxeas shorter than $500 \mu \mathrm{m}$ are very rare). Oxeas III, extremely thin, with acerate tips, always in tracts, more than $4600 \mu \mathrm{m}$ in length and 5-10.2-12 $\mu \mathrm{m}$ in width. Calthrops, usually 

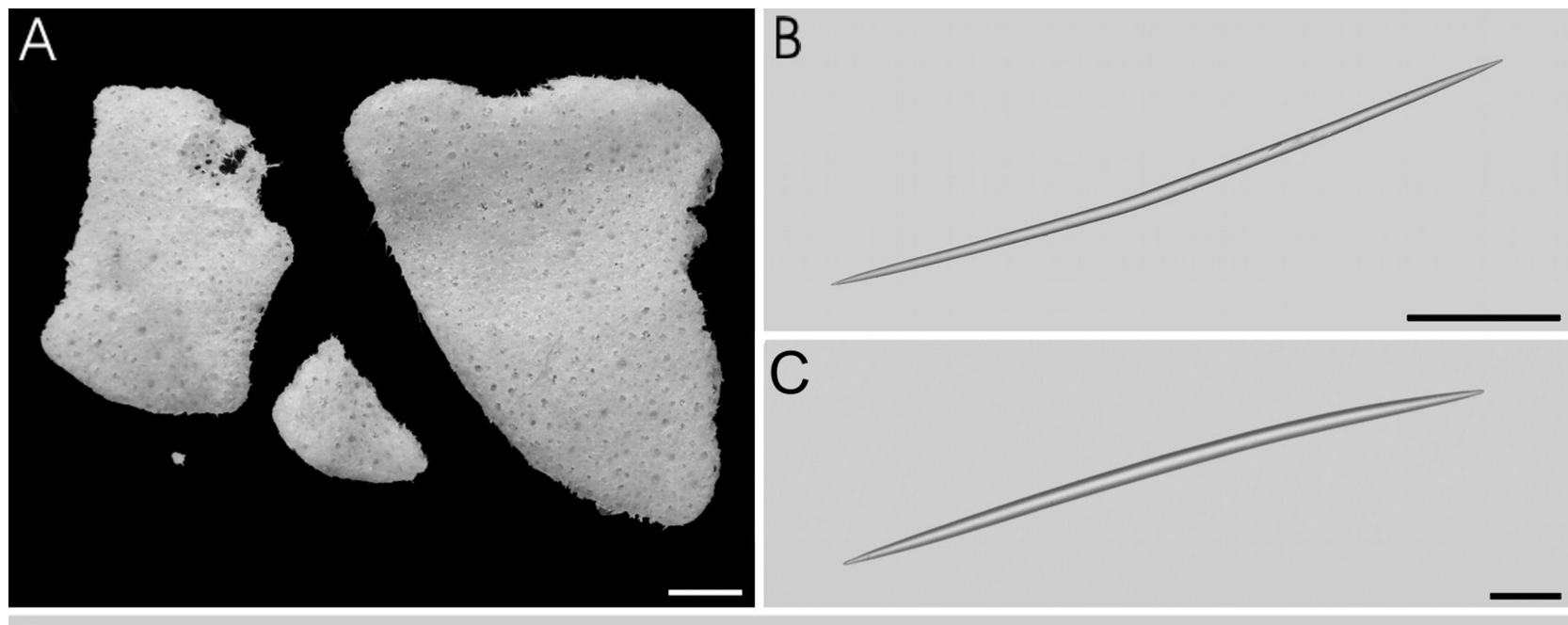

D

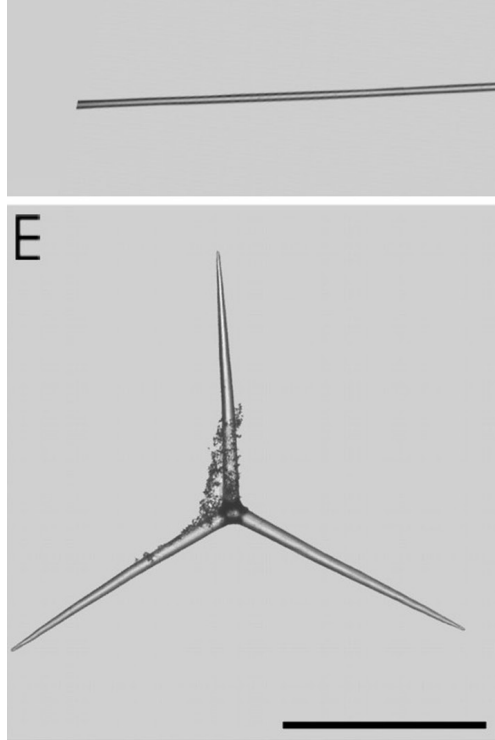

C
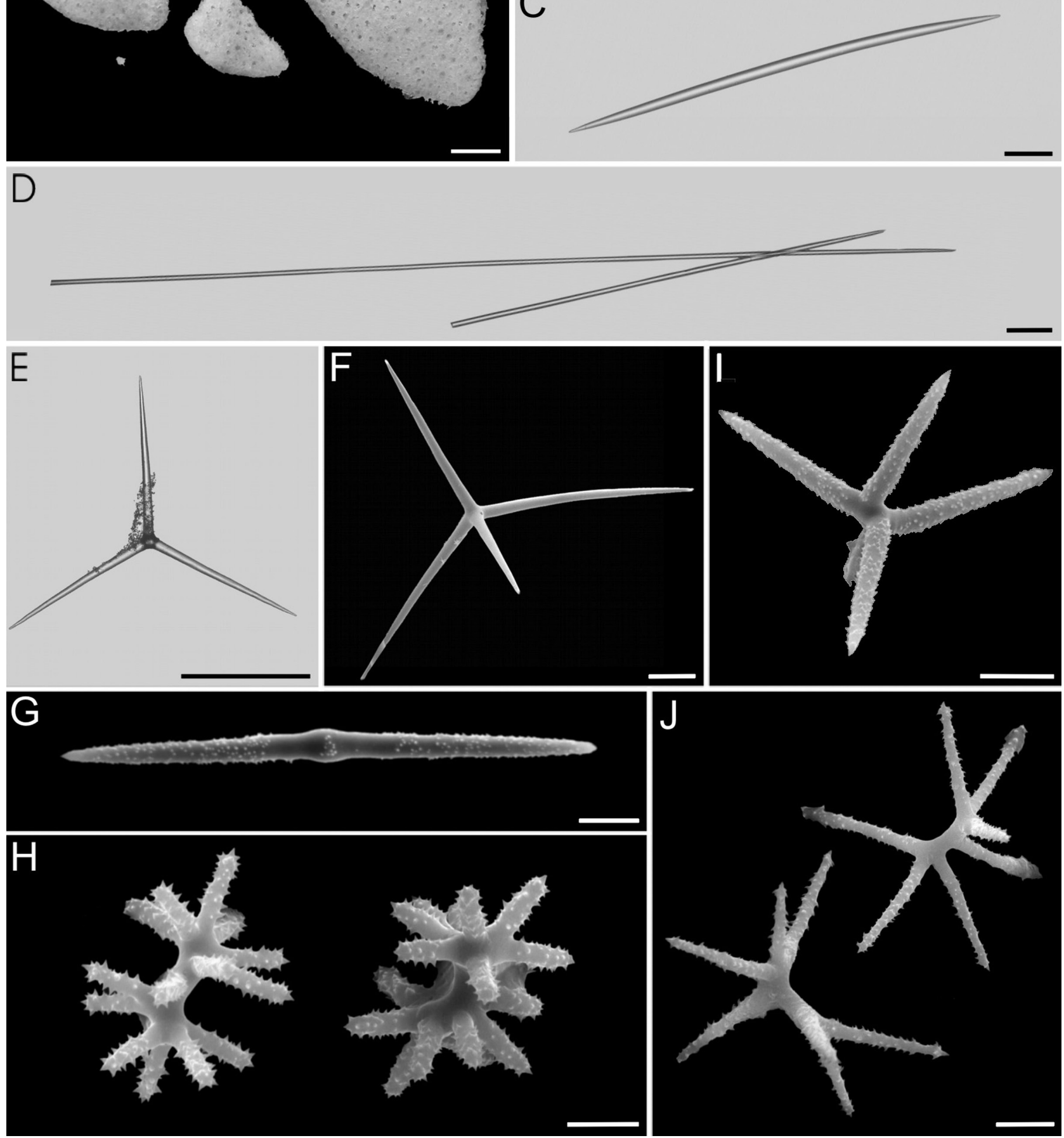

FIG. 3. - Poecillastra maremontana n. sp. A, schizotype (MNRJ 12563). B, Oxea I. C, Oxea II. D, Oxea III (broken). E-F, Calthrops. G, Acanthomicroxea. H, Spirasters. I, Plesiaster I. J, Plesiasters II (metasters). Scale: A, 1 cm; B, $500 \mu \mathrm{m} ; \mathrm{C}-\mathrm{F}, 100 \mu \mathrm{m} ; \mathrm{G}, \mathrm{I}, 10 \mu \mathrm{m} ; \mathrm{H}, \mathrm{J}, 5 \mu \mathrm{m}$. 
equiangulated, with equal rays, actines 272-494.2-776 $\mu \mathrm{m}$ in length and 19-30.5-39 $\mu \mathrm{m}$ in width. Microscleres are slightly curved and centrotylote acanthomicroxeas, $106-126.1-158 \mu \mathrm{m}$ in length and 2.4- $4.4-5 \mu \mathrm{m}$ in width; spiraster 14-16.5-22 $\mu \mathrm{m}$ in length; and two categories of plesiaster with 26-45.5-74 and 17-24.3-31 $\mu \mathrm{m}$ (ranging from plesiaster to amphiaster).

Etymology. The specific epithet refers to the species seamount habitat ("mare", Latin for sea, "montana", Latin for montane).

Distribution. Currently known only from its type locality - Juan Fernandez seamounts, Chile.

Remarks. Aside from this new species, only two other species of Poecillastra possess three categories of oxeas: P. japonica (Thiele, 1898) and P. tenuilaminaris sensu Green and Bakus (1994) (see Table 1).

Poecillastra japonica has larger oxeas, approximately the same length as those in this new species but 5-6 times stouter. The intermediary sized oxeas are also much stouter in $P$. japonica than in the new species, and the smaller oxeas are larger than $2500 \mu \mathrm{m}$, whereas in the new species the smallest oxeas are only $315 \mu \mathrm{m}$. The new species has two plesiasters, with $P$. japonica reportedly having only a single category.

Green and Bakus (1994) described a specimen of $P$. tenuilaminaris from California with three categories of oxeas, similar to our new species, whereas previous records noted only one category (Sollas, 1888; de Laubenfels, 1932). Nevertheless, oxeas in the new species are much longer, the largest category reaching over $4600 \mu \mathrm{m}$ in length, while the oxeas in the Californian sponge are smaller than $2750 \mu \mathrm{m}$ in length.

Three categories of oxeas, one of them larger than $4600 \mu \mathrm{m}$, three categories of streptasters (one of spirasters and two of plesiasters), one category of calthrops and centrotylote microxeas distinguish $\mathrm{Po}$ ecillastra maremontana $\mathrm{n}$. $\mathrm{sp}$. from all other species of the genus.

\section{Poecillastra sinetridens $\mathrm{n} . \mathrm{sp}$.} (Figs. 4, Table 1)

Type material. Holotype, Chile: MHNG 34993; off Zapallar (Valparaiso, 32 $33^{\prime} \mathrm{S} 71^{\circ} 43^{\prime} \mathrm{W}$ ), $300 \mathrm{~m}$ depth, leg. H. Andrade, 09/ iv/1979. Schizotype MNRJ 9392.

Comparative material. Poecillastra compressa antarctica Koltun, 1964 (holotype, ZIL 10862).

Diagnosis. Poecillastra without calthrops or any other kind of triaenes. Oxeas always larger than 3000 $\mu \mathrm{m}$ long, and microxeas can be over $300 \mu \mathrm{m}$ long.

Description. The single specimen consists of two fragments, the largest one $2.5 \times 1.5 \times 1 \mathrm{~cm}$ in size (Fig. 4A). The irregular surface is rough, sometimes hispid with large oxeas projecting through it $(3000 \mu \mathrm{m}$ be- yond the surface). The sponge is soft and compressible. The colour is beige in ethanol, with some darker spots.

Skeleton: Ectosomal skeleton has no specialization. It is a tangential layer of microxeas with a marked concentration of spirasters and plesiasters, the former being more abundant. Choanosomal skeleton confused. Spirasters and plesiasters are also present, with plesiasters being more abundant in this region. Microxeas are found in a smaller quantity.

Spicules (Fig. 4B-H): Megascleres are oxeas in a single size category, smooth, slightly curved, with acerate tips sharpening gradually (rarely with one rounded tip), 3003-4253.4-5720 $\mu \mathrm{m}$ long and 48-68.4$82 \mu \mathrm{m}$ thick. Microscleres are slightly curved acanthomicroxeas, 97-213.9-349 $\mu \mathrm{m}$ long and 2.4-4.9-8 $\mu \mathrm{m}$ thick. Spirasters 17-19.2-22 $\mu \mathrm{m}$ long, and plesiasters 15-24.0-32 $\mu \mathrm{m}$ long.

Etymology. The new species is named "sinetridens" due to its unique character of lacking calthrops or any other type of triaenes, which occur in all other species of the genus (sine, Latin for without; tridens, trident).

Distribution. So far known only from its type locality, off Zapallar, central Chile.

Remarks. The possession of asters is a widespread feature within the order Astrophorida. Sponges belonging to the Pachastrellidae typically have streptasters, microxeas (in most cases) and microrhabds as microscleres (see Table 1). Megascleres include a varied set of tetraxons (Maldonado, 2002). Most genera of Pachastrellidae have calthrops and/or triaenes. The occurrence of microxeas in a single category and streptasters including plesiasters indicates that this new species belongs to Pachastrellidae. The apparent absence is assumed to be a secondary loss of triaenes in this new species. This is unique and as such its allocation to $\mathrm{Po}$ ecillastra requires further discussion.

Five out of the 12 currently valid genera of Pachastrellidae (Maldonado, 2002) are ruled out on the basis of their microscleres: absence of microxeas in Pachastrella Schmidt, 1868 and Thenea Gray, 1867; and possession of different kinds of microscleres in Acanthotriaena Vacelet, Vasseur and Lévi, 1976 (raphides), Dercitus Gray, 1867 (toxas), and Stoeba Sollas, 1888 (microrhabd-like sanidasters). Four genera are excluded on the basis of their megasclere morphology: Ancorella Lendenfeld, 1906 has strongyloxeas transitional to strongyles; $\mathrm{Bra}$ chiaster Wilson, 1925 has short-shafted triaenes and/or mesotriaenes that become mesotrider desmas; Cladothenea Koltun, 1964 has cladotyles; and Triptolemma de Laubenfels, 1955 has exclusively short-shafted mesotriaenes with diversely branched cladi. Vulcanella Sollas, 1886 possesses specialized cribriporal oscula and one or more microsclere categories bearing an annulate decoration (Maldonado, 2002). Characella Sollas, 1886 also contains species with streptasters and microxeas as microscleres. However, the fact that the streptasters in 

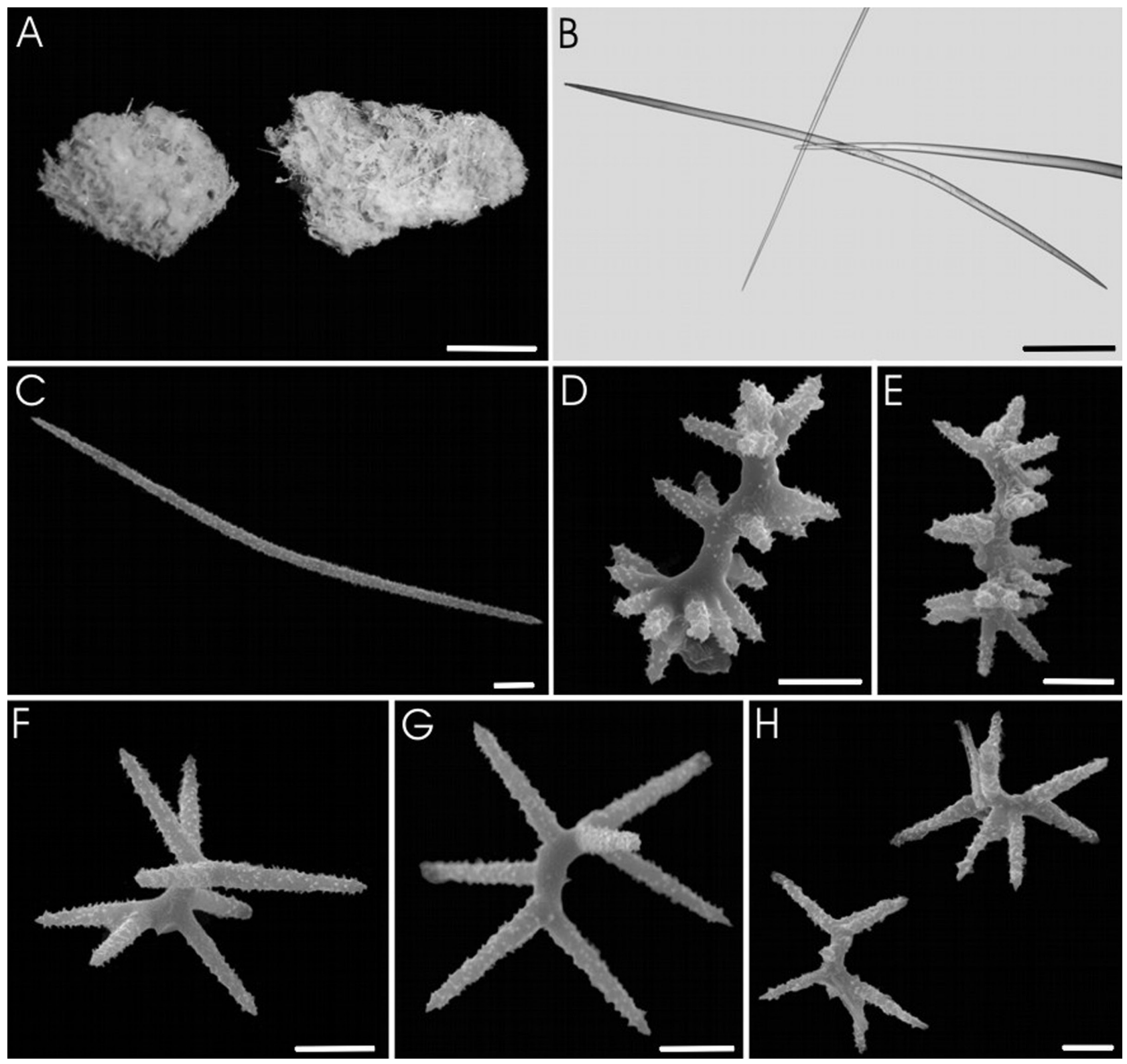

FIG. 4. - Poecillastra sinetridens n. sp. A, schizotype (MNRJ 9392). B, Oxeas. C, Acanthomicroxea. D-E, Spirasters. F-H, Plesiasters (F, H, metasters). Scale: A, $1 \mathrm{~cm}$; B, $500 \mu \mathrm{m}$; C-H, $5 \mu \mathrm{m}$.

Characella are never spirasters, and that its microxeas are always in at least two size categories, also excludes the assignment of the new species to this genus Lerner $e t$ al. (2004) and Esteves and Muricy (2005) described new species recognizable, among other traits, by the absence of microscleres (Guitarra sepia Lerner, Hajdu, Custódio and van Soest 2004 and Stelletta anasteria Esteves and Muricy, 2005). While this assumed secondary loss of triaenes is a negative attribute, and unwisely applied at the genus level, we contend it is a valid species trait. The decision to allocate the new species in Poecillastra stems from its possession of a set of microscleres which comprises spirasters, plesiasters and acanthose microxeas in a single category, precisely matching the characteristic of other species in this genus.
At the species level there are five species that have the same spicule set as Poecillastra sinetridens n. sp., aside from the presence of calthrops absent in the new species, viz. one category each of oxeas and microxeas, and two categories of streptasters. These are $P$. antarctica Koltun, 1964 (as P. compressa a., see below); $P$. compressa; $P$. eccentrica; $P$. laminaris (sensu Lévi and Lévi, 1989 [not sensu Sollas (1888), with two categories of oxeas]); and $P$. tenuilaminaris (not sensu Green and Bakus, 1994 [with three categories of oxeas]).

Poecillastra compressa sensu Boury-Esnault and van Beveren (1982) has oxeas which can be considerably shorter $(\mathrm{ca} .1000 \mu \mathrm{m})$ than those of the new species. It also has a third category of asters reach- 
ing $80 \mu \mathrm{m}$ in length, not seen in the Chilean species. Poecillastra compressa sensu Pulitzer-Finali (1993) has oxeas reaching only $3500 \mu \mathrm{m}$ in length, as well as microxeas which are smaller than $135 \mu \mathrm{m}$, and is thus quite distinct from the new species. Poecillastra antarctica and P. eccentrica (both holotypes re-examined, ZIL 10862 and BMNH 1926.10.1.95, respectively) have oxeas as large as those in $P$. sinetridens $\mathrm{n}$. sp., although both possess smaller microxeas, up to $190 \mu \mathrm{m}$ in length only. In addition, oxeas in P. eccentrica can be very small, ca. $420 \mu \mathrm{m}$ in length.

Poecillastra laminaris sensu Lévi and Lévi, 1989 has smaller microxeas and metasters with a much smaller size range than $P$. sinetridens $\mathrm{n}$. sp. Sollas's (1888) sponge differs in having two categories of oxeas, the smaller one up to $3500 \mu \mathrm{m}$ long only, while the new species has oxeas always longer than $3000 \mu \mathrm{m}$, and sometimes longer than $5000 \mu \mathrm{m}$. Additionally, Sollas's material was reported to possess trichoxeas, clearly differentiating it from the new species.

Finally, P. tenuilaminaris (sensu Sollas, 1888; Lebwohl, 1914) has smaller oxeas and microxeas and was also reported from greater depths off Japan, so it differs both morphologically and biogeographically from the new species. Additional records of P. tenuilaminaris need further comments. Dendy's (1916) description appears to concern a distinct taxon. He outlined seven points of divergence between the Indian and Sollas's (1888) original description (from Japan). Significant among these are the presence of long hair-like oxeas, the smaller size of the metasters which show no tendency to pass into plesiasters, and the rarer tetraxons and microxeas in Dendy's specimen. Further distinction stems from the possible shallow water habitat of his specimen, collected in the tropical islands of the Amirantes Archipelago, where the fauna has very little in common with that of Japan. Dendy's sponge appears to more closely resemble $P$. laminaris from Indonesia, which also possesses a second category of large hair-like oxeas. No striking morphological distinction is apparent when the two descriptions are compared, and the main trait setting them apart is the relatively deep water habitat of $P$. laminaris. Both specimens need to be compared in greater detail to correctly allocate Dendy's specimen. Poecillastra tenuilaminaris has also been recorded from California in a series of publications (de Laubenfels, 1932; Dickinson, 1945; Green and Bakus, 1994). Judging from each of the descriptions, these appear to conform to the Japanese population, making the species highly disjunct. A thorough revision of morphological characters, especially a detailed SEM study of asterose microscleres is required to verify the status of these populations.

In spite of the greater or lesser diagnostic trends noted above when P. sinetridens n. sp. was compared with other species, the main immediate diagnostic feature is the absence of triaenes.

\section{DISCUSSION}

\section{Spicule loss}

Tetractinellid sponges (Astrophorida and Spirophorida, sensu Borchiellini et al., 2004) are mainly characterized by the possession of tetractinal megascleres and microscleres (asterose forms and derivatives) (Hooper and van Soest, 2002), though examples of whole evolutionary lineages which have lost one or more of these diagnostic features are known (e.g. Asteropus spp., Jaspis spp.). According to Hooper and van Soest (2002), microscleres are the major taxonomic characters in tetractinellids, but even these may be totally absent (e.g. Stelletta anasteria).

Hooper and van Soest (2002) have recognized eight genera belonging to Astrophorida with a reduction or total loss of triaenes. Six of them belong to Ancorinidae (Jaspis Gray, 1867; Asteropus Sollas, 1888; Dorypleres Sollas, 1888; Holoxea Topsent, 1892; Melophlus Thiele, 1899; and Rhabdastrella Thiele, 1903), one to Pachastrellidae (Characella Sollas, 1886), and Lamellomorpha Bergquist, 1968, which is incertae sedis as to family allocation. Most of these genera have a tangential layer of megascleres in the ectosomal skeleton (e.g. Asteropus, Holoxea, Jaspis, Lamellomorpha and Melophlus; cf. Hajdu and van Soest, 1992), which may substitute for any possible structural integrity shortcoming arising from the loss of triaenes. Currently, this recurrent pattern is not judged synapomorphic, so the development of a variously neat tangential layer of oxeote megascleres in these genera might be understood as a possible convergent response to solve the likely parallel problem of triaene loss.

\section{Comments upon other Poecillastra}

Koltun (1964) did not mention the presence of microxeas in the original description of $P$. compressa antarctica, which would prevent the classification of this subspecies in Poecillastra. However, the reexamination of its holotype (ZIL 10862) revealed the presence of these spicules (Table 1), straight to very curved. Remarkably, no single morphological character observed by us in the fragment of the holotype re-examined matches the description of Koltun, which makes us wonder whether we have observed the same sponge. It is noteworthy that the micrometric values obtained here for the oxeas and plesiasters (metasters sensu Koltun, 1964) were much larger than values originally reported by Koltun. In spite of this confusion, these larger spicules serve the purpose of establishing the status of $P$. compressa antarctica as distinct from typical $P$. compressa. We prefer to raise Koltun's subspecies to full species status, $P$. antarctica, because the meaning of subspecies ranking in sponge classification is absolutely not agreed upon (Lopes et al., in press), and emphasizing the markedly allopatric distribution of both. P. compressa sensu Boury-Esnault and 


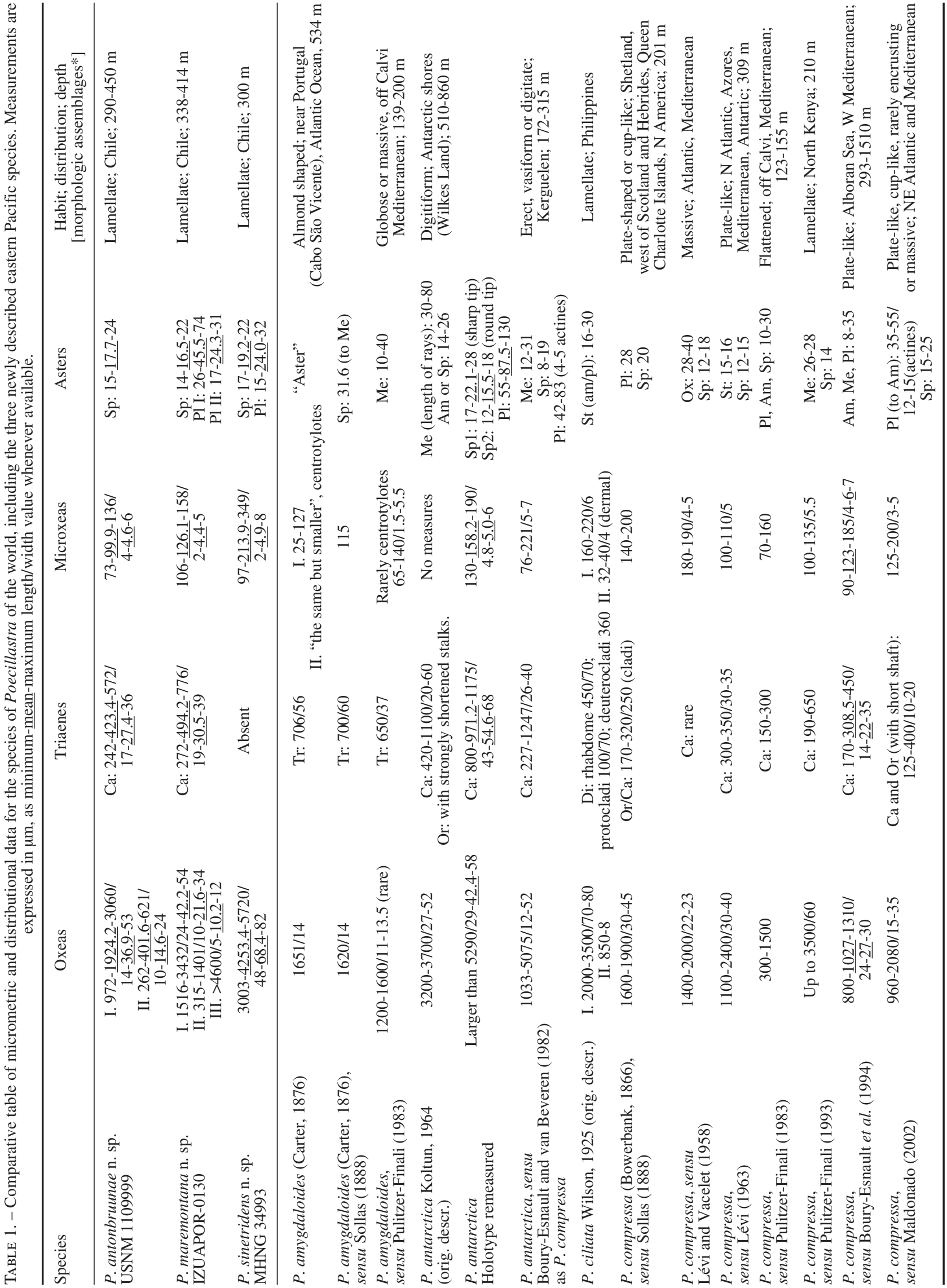


486 - M.S. CARVALHO et al.

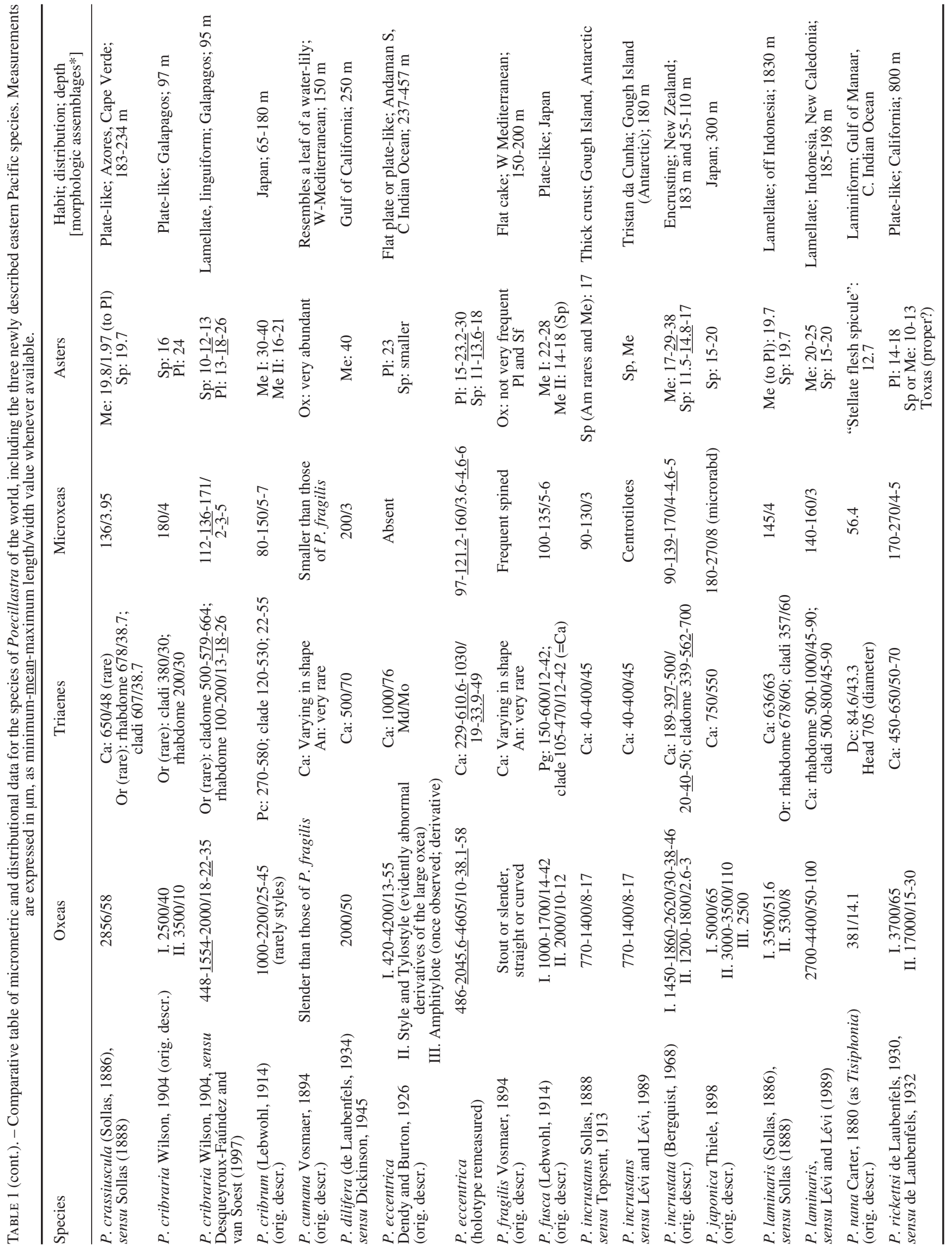




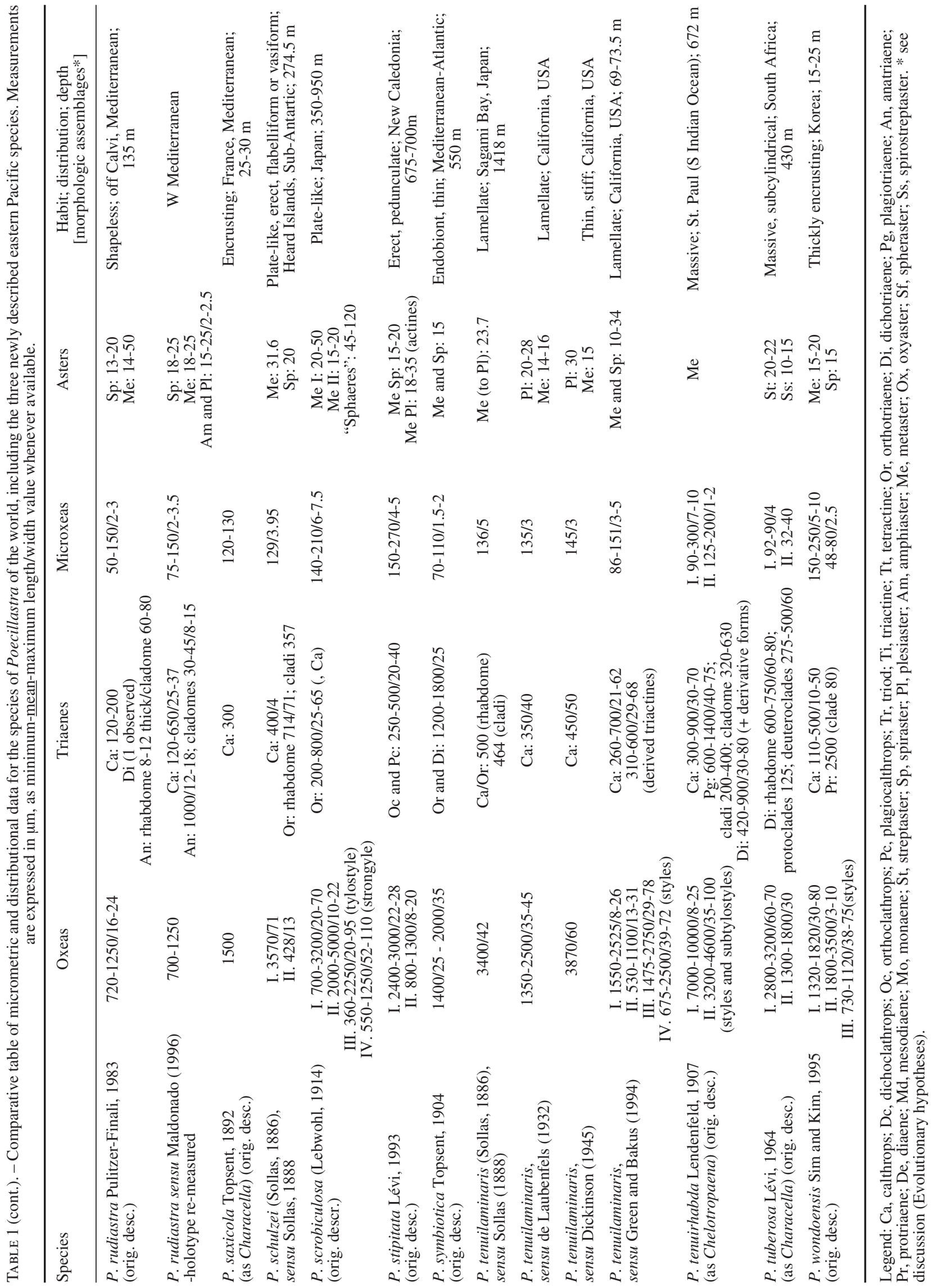


van Beveren (1982) fits much better in $P$. antarctica, due to its possession of oxeas up to $5075 \mu \mathrm{m}$ in length, calthrops of up to $1247 \mu \mathrm{m}$ and one category of plesiasters of up to $83 \mu \mathrm{m}$.

Other records of Poecillastra compressa also need revision. Pulitzer-Finali (1983) reported an alleged $P$. compressa from the Mediterranean possessing oxeas as small as $300 \mu \mathrm{m}$ in length; while Pulitzer-Finali (1993), working on materials from the northern Kenyan coast, reported oxeas up to $3500 \mu \mathrm{m}$ in length and calthrops of up to $650 \mu \mathrm{m}$. These two specimens may belong to different species and should be re-analyzed in detail, which has not been possible here.

Poecillastra crassiuscula (Sollas, 1886) and $P$. incrustans Sollas, 1888 were suggested as junior synonyms of $P$. compressa by Maldonado (2002). We disagree with this proposal as oxeas in P. incrustans are thinner and have a smaller size range than in $P$. compressa (Table 1). P. crassiuscula has larger oxeas and tetraxons. In addition, tetraxons (calthrops/orthotriaenes) are also larger in $P$. crassiuscula. It would be interesting to revise the microscleres of the three species in SEM to figure how micromorphologic features vary among them, but we did not have access to these materials in this study. Boury-Esnault et al.'s (1994) redescription of $P$. compressa, is the only one in which SEM was used for the species above, and only a single spicule of each microsclere category was illustrated.

Poecillastra rickettsi was suggested as a likely synonym of $P$. tenuilaminaris by Maldonado (2002). Above we have already used the occurrence of hairlike oxea to argue for the unlikelihood of Dendy's (1916) specimen being properly identified in $P$. tenuilaminaris. $P$. rickettsi has the largest hair-like oxeas described from any species of Poecillastra (Table 1), being over 4 times larger than the largest oxeas reported from $P$. tenuilaminaris (3870 $\mu \mathrm{m}$; Dickinson, 1945), and as such, deserving status as a valid species.

Five Pacific species of Pachastrella listed in the WPD (Van Soest et al., 2008) are better assigned to Poecillastra (P. Cardenas, pers.comm.), viz. P. cribrum Lebwohl, 1914; P. dilifera de Laubenfels, 1934 [sensu Dickinson (1945)]; P. fusca Lebwohl, 1914; P. incrustata Bergquist, 1968; and P. scrobiculosa Lebwohl, 1914. According to Dickinson (1945), P. dilifera has microrhabds $200 \mu \mathrm{m}$ long, better considered to be true microxeas. All these species possess microxeas instead of microrhabds (oval microstrongyles).

\section{Evolutionary hypotheses}

A few repetitive sets of spicules were found in species groups within Poecillastra sensu van Soest et al. (2008). These are as follows: (A) species bearing dichotriaenes [6 spp.: ciliata, nana, rudiastra sensu Pulitzer-Finali (1983), symbiotica, tenuirhabda, tuberosa]; (B) species with anatriaenes (3 spp.: cumana, fragilis, rudiastra); (C) species with disproportionately long oxeas (length $>200 x$ width, 7 spp.: incrustata, laminaris, maremon- tana, ricketsi, scrobiculosa, tenuirhabda, wondoensis); (D) species with two categories of microxea [Characella-like, 5 spp.: amygdaloides sensu Carter (1876), ciliata, tenuirhabda, tuberosa, wondoensis]; and (E) species bearing asterose microscleres reaching over 70 $\mu \mathrm{m}$ in diameter (2 spp.: antarctica, maremontana). The distinction between a true calthrops and an orthotriaene can be quite subtle when alleged rhabdomes are nearly as long as the cladi. For this reason, we preferred not to propose possible species groups among species bearing such triaenes, in the absence of their detailed revision. Fifteen species do not belong into obviously recognizable groups, which reflects the difficulty of performing phylogenetic analyses with these sponges on the basis of morphological characters alone.

Cross-checking assemblages for shared species allows one to recognize a triad of species corroborated by two congruent traits. Poecillastra ciliata, $P$. tenuirhabda and $P$. tuberosa share the possession of dichotriaenes as well as two categories of microxeas, which is suggestive of likely phylogenetic affinity. No additional congruent traits were observed.

Figure 5 shows the approximate distribution of each of these recognized morphological assemblages (A-E). Group (A) reflects an apparent relictual Tethyan distribution, and group (B) is restricted to the Mediterranean. The other groups are notorious for their largely disjunct distributions. This is the case too for the species triad highlighted above, occurring in the Philippines, Saint Paul Isl. and South Africa, and spreading across the southern Indian Ocean and western Pacific. Widespread Indo-West Pacific species are known from a variety of sponge genera (Hooper and Lévi, 1994; van Soest, 1994; van Soest and Hajdu, 1997; Fromont et al., 2010). In many of these, several records punctuate the known distribution range of species [e.g. Acarnus bergquistae van Soest, Hooper and Hiemstra., 1991; A. bicladotylus Hoshino, 1981; A. wolffgangi Keller, 1889; Clathria procera (Ridley, 1884); cf. van Soest et al., 1991; Hooper and Lévi, 1994], so that discontinuity is not so striking.

Group (D) considerably matches the distribution observed in group (A), but records for the Mediterranean (rudiastra, symbiotica) and Central Indian ocean (nana) in (A) are replaced by a record for Korea (wondoensis) in (D), thus rendering group (D) more widespread, and less likely explained as a relictual Tethyan distribution. Group (C) has a nearly amphi-Pacific distribution, with an off-shoot in the southern Indian ocean. The complete absence of any Atlantic records here suggests that any phylogenetic signal present in this assemblage may be a consequence of trans-Pacific evolutionary tracks (e.g. Sluys, 1994; Hajdu and Desqueyroux-Faúndez, 2008).

\section{Poecillastra vs. Characella}

The number of categories of microxeas along with the form of streptasters seem to be the most obvious 

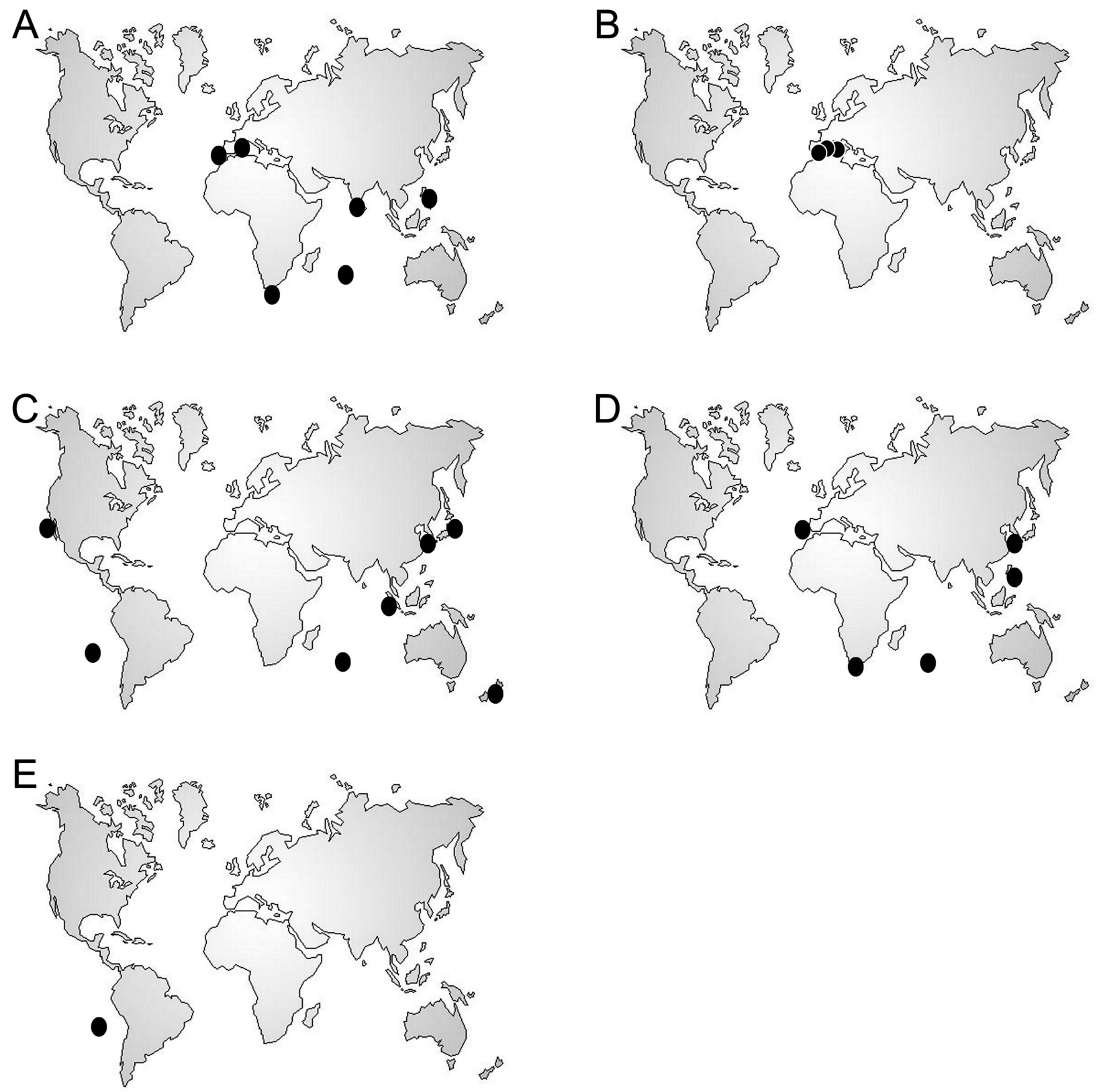

FIG. 5. - Approximate distribution of each assemblage in Poecillastra defined by shared sets of spicules. (A) species bearing dichotriaenes (6 spp.), (B) species with anatriaenes (3 spp.), (C) species with disproportionately long oxeas (length $>200 \mathrm{x}$ width, $7 \mathrm{spp}$.), (D) species with two categories of microxea (Characella-like, $5 \mathrm{spp}$.), (E) species bearing asterose microscleres reaching over $70 \mu \mathrm{m}$ in diameter ( $2 \mathrm{spp}$.).

characters to distinguish Characella and Poecillastra. The latter always includes streptasters with twisted shafts (amphiasters, metasters, plesiasters, spirasters and/or transitional forms), while in Characella streptasters have straight shafts (amphiasters, sanidasters and/or transitional forms) (Maldonado, 2002). Maldonado (1996, 2002) still emphasized the location of triaenes as diagnostic. These supposedly occur in the ectosome and choanosome in Poecillastra, but are restricted to subectosomal locations in Characella.
We recognize 28 species of Poecillastra, as briefly characterized in table 1: P. amygdaloides; $P$. antarctica; $P$. antonbruunae n. sp.; $P$. compressa; $P$. crassiuscula $; P$. cribraria; P. cribrum; P. cumana; $P$. dilifera; $P$. eccentrica; $P$. fragilis; $P$. fusca; $P$. incrustans; $P$. incrustata; $P$. japonica; $P$. laminaris; $P$. maremontana sp.nov; $P$. nana; $P$. rickettsi; $P$. rudiastra; $P$. saxicola; $P$. schulzei; $P$. scrobiculosa; $P$. sinetridens $\mathrm{n}$. $\mathrm{sp}$.; $P$. stipitata; $P$. symbiotica; $P$. tenuilaminaris; and $P$. wondoensis.

An identification key for the 20 species of Poecillastra occurring in the Pacific Ocean is given below. 


\section{Identification key for Pacific Poecillastra}

1. Absence of triaenes P. sinetridens $\mathrm{n} . \mathrm{sp}$.

- Presence of triaenes .2

2. Triaenes are dichocalthrops 3

- Triaenes never include dichocalthrops .................... 4

3. Dichocalthrops with rhabdome up to $450 \mu \mathrm{m}$ long; the smaller category of oxeas up to $850 \mu \mathrm{m}$ long.... P. ciliata

- Dichocalthrops with rhabdome larger than $600 \mu \mathrm{m}$ long; the smaller category of oxeas larger than 1300 $\mu \mathrm{m}$ long P. tuberosa

4. Triaenes are only orthotriaenes (rhabdome different from the cladi), no calthrops

- Triaenes include calthrops P. cribraria

5. Oxeas in three categories .6

- Oxeas in one or two categories ..8

6. Microxeas larger than $180 \mu \mathrm{m}$ and only one category of asters. P. japonica

- Microxeas smaller than $160 \mu \mathrm{m}$ long and more than one category of asters ...7

7. The larger category of oxeas may be larger than 4600 $\mu \mathrm{m}$ and is less than $15 \mu \mathrm{m}$ thick; three categories of asters (one of spirasters and two of plesiasters) ...... P. maremontana n. sp.

- Oxeas never larger than $3400 \mu \mathrm{m}$, but up to 78 $\mu \mathrm{m}$ thick; two categories of asters (metasters and spirasters) $P$. tenuilaminaris sensu Green and Bakus (1994)

8. Oxeas in one category. .9

- Oxeas in two categories 13

9. Oxeas can be longer than $3000 \mu \mathrm{m}$ 10

- Oxeas smaller than $2500 \mu \mathrm{m}$

10. Calthrops with cladi up to $500 \mu \mathrm{m}$ long P. tenuilaminaris sensu Sollas (1888) and Dickinson (1945)

- Calthrops with larger cladi (up to $1000 \mu \mathrm{m}$ ) .P. laminaris sensu Lévi and Lévi (1989)

11. Metasters only up to $16 \mu \mathrm{m}$ long ........ . tenuilaminaris sensu de Laubenfels (1932)

- Metasters up to $40 \mu \mathrm{m}$ long .12

12. Microxeas short and stout (80-150/5-7 $\mu \mathrm{m})$

- Microxeas longer and slender $(200 / 3 \mu \mathrm{m})$ P. cribrum P. dilifera sensu Dickinson (1945)

13. Megascleres include oxeas $5000 \mu \mathrm{m}$ long or larger
- Megascleres include oxeas always smaller than $3500 \mu \mathrm{m}$ long

14. Oxeas can be longer than $10000 \mu \mathrm{m}$, microxeas up to $270 \mu \mathrm{m}$ long .................................... P. rickettsi

- Oxeas shorter than $6000 \mu \mathrm{m}$, microxeas shorter than $210 \mu \mathrm{m}$

15. Larger oxeas slender ( $8 \mu \mathrm{m}$ thick), microxeas shorter than $150 \mu \mathrm{m}$, metasters up to $20 \mu \mathrm{m}$ long only ...................... laminaris sensu Sollas (1888)

- Larger oxeas stouter (10-22 um thick), microxeas 140-210 $\mu \mathrm{m}$ long, metasters up to $50 \mu \mathrm{m}$ long ........ P. scrobiculosa

16. Triaenes include protriaenes longer than $2000 \mu \mathrm{m}$ P. wondoensis

- Triaenes of distinct morphology, shorter than 1000 $\mu \mathrm{m}$

17. Microxeas up to $270 \mu \mathrm{m}$ long P. stipitata

- Microxeas up to $170 \mu \mathrm{m}$ long only 18

18. Oxeas II are 262-621 $\mu \mathrm{m}$ long, asters in a single category $P$. antonbruunae $\mathrm{n} . \mathrm{sp}$.

- Oxeas never shorter than $1000 \mu \mathrm{m}$, asters in two categories

19. Oxeas always thicker than $10 \mu \mathrm{m}$, plagiotriaenes present next to calthrops .............................. . fusca

- One category of oxeas much thinner (1200$1800 / 2.6-3 \mu \mathrm{m})$, triaenes are calthrops only $P$. incrustata

\section{ACKNOWLEDGEMENTS}

We are indebted to Dr. Rob van Soest for the loan of the holotype of Poecillastra antonbruunae n. sp. (subsequently deposited in the USNM), and to Dr. V. Häussermann for donating the holotype of $P$. maremontana $\mathrm{n}$. sp. and R. Vega for the collection of the specimen. We also thank Dr. Emma Sherlock and Dr. Claire Valentine for loaning the slides of the holotype of P. eccentrica for comparison, and Dr. Olga Sheiko for loaning the holotype of $P$. antarctica. Dr. John Hooper and an anonymous referee made important suggestions for improvement of the clarity of the arguments presented. The authors are also thankful to Márcia Atthias and Noêmia Rodrigues for SEM facilities at the Departamento de Microscopia Eletrônica de Varredura of the Instituto de Biofísica Carlos Chagas Filho/ UFRJ and to Elivaldo de Lima for SEM operation at the Centre for Scanning Electron Microscopy of the Museu Nacional/UFRJ. The establishment of this centre was made possible by a grant from PETROBRAS, and is part of the "Thematic Network for Marine Environmental Monitoring". We further thank CAPES (Coordenação de Aperfeiçoamento de Pessoal de Nível 
Superior), CNPq (Conselho Nacional de Desenvolvimento Científico e Tecnológico), FAPERJ (Fundação do Amparo à Pesquisa do Estado do Rio de Janeiro), and the Fondation Claraz, Geneva, for providing grants and/or fellowships.

\section{REFERENCES}

Borchiellini, C., C. Chombard, M. Manuel, E. Alivon, J. Vacelet and Boury-Esnault, N. -2004. Molecular phylogeny of Demospongiae: implications for classification and scenarios of character evolution. Mol. Phylogenet. Evol., 32: 823-837.

Boury-Esnault, N. and G. van Beveren. - 1982. Les démosponges du plateau continental de Kerguelen-Heard. Com. Nat. Fr. Rech. Antarct., 52: 9-175.

Boury-Esnault, N., M. Pansini and M.J. Uriz. - 1994. Spongiaires bathyaux de la mer d'Alboran et du golfe ibero-marocain. Mem. Mus. Nat. Hist. Nat., 160: 1-174.

Bowerbank, J.S. - 1866. A Monograph of the British Spongiadae. Vol. 2. Ray Society, London.

Burres, N.S., S. Sazesh, G.P. Gunawardana and J.J. Clement. 1989. Antitumor activity and nucleic acid binding properties of Dercitin, a new acridine alkaloid isolated from a marine Dercitus species sponge. Cancer Res., 49: 5267-5274.

Burton, M. - 1930. Report on a collection of sponges from South Georgia and from Campbell Island, South Pacific, obtained by Dr. Kohl-Larsen. Senckenbergiana, 12(6): 331-335.

Burton, M. - 1959. Sponges. Sci. Rep. John Murray Exp. 1933-34, 10(5): 151-281.

Carter, H.J. - 1880. Report on Specimens dredged up from the Gulf of Manaar and presented to the Liverpool Free Museum by Capt. W.H. Cawne Warren. Ann. Mag. Nat. Hist., (5)5(30): 437-457, pls XVIII-XIX.

Chombard, C., N. Boury-Esnault and S. Tillier. - 1998. Reassessment of homology of morphological characters in tetractinellid sponges based on molecular data. Syst. Biol., 47: 351-366.

Dendy, A. - 1916. Report on the Homosclerophora and Astrotetraxonida collected by H.M.S. 'Sealark' in the Indian Ocean. In: Reports of the Percy Sladen Trust Expedition to the Indian Ocean in 1905, Volume 6. Trans. Linn. Soc. London, (2), 17(2): 225-271, pls 44-48.

Dendy, A. and M. Burton. - 1926. Report on some deep-sea sponges from the Indian Museum collected by the R.I.M.S. 'Investigator'. Part I. Hexactinellida and Tetractinellida (pars). Rec. ind. Mus., 28(4): 225-248.

Desqueyroux-Faúndez, R. and R.W.M. van Soest. - 1997. Shallow waters Demosponges of the Galapagos Islands. Rev. Suiss. Zool., 104 (2): 379-467.

Dickinson, M.G. - 1945. Sponges of the Gulf of California. Allan Hancock Pac. Exp. 11(1): 1-252.

Esteves, E.L. and G. Muricy. - 2005. A new species of Stelletta (Demospongiae, Astrophorida) without microscleres from Abrolhos Archipelago, northeastern Brazil. Zootaxa, 1006: 43-52.

Fromont, J., B. Alvarez, O. Gomez and E. Roberts - 2010. Tetrapocillon (Demospongiae: Poecilosclerida: Guitarridae) in Australia, with the description of a new species. Rec. Aus. Mus. 26: $70-86$.

Green, K.D. and G.J. Bakus. - 1994. Taxonomic Atlas of the Benthic fauna of the Santa Maria Basin and Western Santa Barbara Channel. Vol. 2 - The Porifera. Santa Barbara Museum of Natural History, Santa Barbara, California.

Gunawardana, G.P., S. Kohmoto and N.S Burres. - 1989. New cytotoxic acridine alkaloids from two deep water marine sponges of the family Pachastrellidae. Tetrahedron Lett., 30(33): $4359-4362$.

Hajdu, E. - 1994. A phylogenetic interpretation of hamacanthids (Demospongiae, Porifera), with the redescription of Hamacan tha popana. J. Zool., 232: 61-77.

Hajdu, E. and R. Desqueyroux-Faúndez. - 2008. A reassessment of the phylogeny and biogeography of Rhabderemia Topsent, 1890 (Rhabderemiidae, Poecilosclerida, Demospongiae). Rev. Suiss. Zool, 115: 377-395.

Hajdu, E. and R.W.M. van Soest. - 1992. A revision of Atlantic Asteropus Sollas, 1888 (Demospongiae), including a descrip- tion of three new species, and with a review of the family Coppatiidae Topsent, 1898. Bijdr. Dierkd., 62(1): 3-19.

Hooper, J.N.A. and C. Lévi. - 1994. Biogeography of Indo-west Pacific sponges: Microcionidae, Raspailiidae, Axinellidae. In: R.W.M. van Soest, Th.M.G. van Kempen and J.-C. Braekman (eds.), Sponges in Time and Space, pp. 191-212. Balkema, Rotterdam.

Hooper, J.N.A. and R.W.M. van Soest. - 2002. Order Astrophorida Sollas, 1888. In: J.N.A. Hooper and R.W.M. van Soest (eds.), Systema Porifera: A Guide to the Classification of sponges, 1, pp 105-107. Klumer Academic/Plenum Publishers, New York.

Kim, D., I.S. Lee, J.H. Jung and S.I. Yang. - 1999. Psammaplin $\mathrm{A}$, a natural bromotyrosine derivative from a sponge, possesses the antibacterial activity against methicillin-resistant Staphylococcus aureus and the DNA gyrase-inhibitory activity. Arch. Pharmacal. Res., 22(1): 25-29.

Koltun, V.M. - 1964. Sponges of the Antarctic. 1 Tetraxonida and Cornacuspongida. In: E.P. Pavlovskii, A.P. Andriyashev and P.V. Ushakov (eds.), Biological Reports of the Soviet Antarctic Expedition (1955-1958), vol.2, pp. 6-133, 443-448. Akademya Nauk SSSR (English translation, 1966, Israel Programme for Scientific Translation).

Laubenfels, M.W. de. - 1932. The marine fauna and fresh-water sponges of California. Proc. U. S. Natl. Mus., 81(4): 1-140.

Lebwohl, F. - 1914. Japanische Tetraxonida, I. Sigmatophora und II. Astrophora metastrosa. J. Coll. Sci. Imp. Univ. Tokyo 35(2): $1-116$, pls. I-IX.

Lendenfeld, R. Von. - 1907. Die Tetraxonia. Wiss. Ergebn. "Valdivia", 11(1-2): i-iv, 59-374, pls. IX-XLVI.

Lerner, C.B., E. Hajdu, M.R. Custódio and R.W.M. van Soest. 2004. Guitarra sepia n.sp. from the southwestern Atlantic (Demospongiae, Poecilosclerida, Guitarridae). First record of a Guitarra without placochelae. Boll. Mus. Inst. Biol. Univers. Genova, 68: 405-411.

Lévi, C. - 1963. Spongiaires d'Afrique du Sud. (3) Tetractinellides. T. Roy. Soc. S. Afr., 37(3): 227-256.

Lévi, C. - 1964. Spongiaires des zones bathyale, abyssale et hadale. Galathea Rep., 7: 63-112, pls. II-XI.

Lévi, C. - 1993. Porifera Demospongiae: Spongiaires bathyaux de Nouvelle-Calédonie, récoltés par le 'Jean Charcot'. Campagne BIOCAL, 1985. In: A. Crosnier (ed.), Résultats des campagnes Musorstom, Volume 11. Mém. Mus. natl Hist. nat. (A, Zool.), 158: 9-87.

Lévi, C. and P. Lévi. - 1989. Spongiaires (Musorstom 1 and 2). In: J. Forest (ed.), Résultats des Campagnes Musorstom, Vol. 4. Mém. Mus. natl Hist. nat. (A, Zool.), 143: 25-103.

Lévi, C. and J. Vacelet. - 1958. Éponges recoltées dans l'Atlantique oriental par le 'President Théodore-Tissier' (1955-1956). Rev. Trav. Inst. Pech. Marit., 22(2): 225-246.

Lopes, D.A., Hajdu E. and Reiswig H.M. - (in press). Taxonomy of Farrea (Porifera, Hexactinellida, Hexactinosida) from the southwestern Atlantic, with description of a new species, and a discussion on the recognition of subspecies in Porifera. Can. J. Zool.

Maldonado, M. - 1996. On the presence of anatriaenes in Pachastrellidae (Porifera: Demospongiae): evidence for a new phylogenetic family concept. J. Nat. Hist., 30: 389-405.

Maldonado, M. - 2002. Family Pachastrellidae Carter, 1875. In: J.N.A. Hooper and R.W.M. van Soest (eds.), Systema Porifera: A Guide to the Classification of sponges, 1, pp. 141-162. Klumer Academic/Plenum Publishers, New York.

Pulitzer-Finali, G. - 1983. A collection of Mediterranean Demospongiae (Porifera) with, in appendix, a list of the Demospongiae hitherto recorded from the Mediterranean Sea. Ann. Mus. Civ. Stor. Nat. Genova, 84: 445-621.

Pulitzer-Finali, G. - 1993. A collection of marine sponges from East Africa. Ann. Mus. Civ. Stor. Nat. Giacomo Doria, 89: 247-350.

Sim, C.J. and Y.A. Kim. - 1995. A Systematic Study on the Marine Sponges in Korea 12. Tetractinomorpha (Porifera: Demospongiae). Kor. J. Syst. Zool., 11 (2): 147-158.

Soest, R.W.M. van. - 1994. Demosponge distribution patterns. In: R.W.M. van Soest, Th.M.G. van Kempen and J.-C. Braekman (eds.), Sponges in Time and Space, pp. 213-223. Balkema, Rotterdam.

Soest, R.W.M. van and E. Hajdu. - 1997. Marine area relationships from twenty sponge phylogenies. A comparison of methods and coding strategies. Cladistics, 13: 1-20. 
Soest, R.W.M. van, J.N.A. Hooper and F. Hiemstra. - 1991. Taxonomy, phylogeny and biogeography of the marine sponge genus Acarnus (Porifera: Poecilosclerida). Beaufortia, 42: 49-88.

Soest, R.W.M. van, N. Boury-Esnault, J.N.A. Hooper, K. Rützler, N.J. de Voogd, B. Alvarez, E. Hajdu, A.B. Pisera, J. Vacelet, R. Manconi, C. Schoenberg, D. Janussen, K.R. Tabachnick and M. Klautau. - 2008. World Porifera database. Available online at http://www.marinespecies.org/porifera. Last consulted June 2010.

Sollas, W.J. - 1886. Preliminary account of the Tetraxinellid sponges Dredged by H.M.S. 'Challenger' 1872-76. Part I. The Choristida. Sci. Proc. r. Dublin Soc. (new series), 5: 177-199.

Sollas, W.J. - 1888. Report on the Tetractinellida collected by H.M.S. 'Challenger' during the years 1873-1876. Rep. Sci. Res. Voy. H.M.S. 'Challenger' 1873-1876, Zool., 25: 1-458.

Thiele, J. - 1898. Studien über pazifische Spongien. I. Japanische Demospongien. Zoologica, 24(1): 1-72, pls. I-VIII.

Topsent, E. - 1892. Diagnoses d'éponges nouvelles de la Méditerranée et plus particulièrement de Banyuls. Arch. Zool. Exp. Gen., 2: 10 (Notes et Revue 6) xvii-xxviii.

Topsent, E. - 1894. Etude monographique dês Spongiaires de
France. I Tetractinellida. Arch. Zool. Exp. Gen., 3(2): 261-400. Topsent, E. - 1904. Spongiaires des Açores. Rés. Camp. Sci. Pr. Albert I ${ }^{o}$ Monaco, 25: 1-280, pls. 1-18.

Topsent, E. - 1913. Spongiaires de l'Expédition Antarctique Nationale Ecossaisse. Trans. Roy. Soc. Edinburgh, 49(3): 579-643, pls. I-VI.

Uriz, M.J. - 2002. Family Ancorinidae Schmidt, 1870. In: J.N.A. Hooper and R.W.M. van Soest (eds.), Systema Porifera: A Guide to the Classification of sponges, 1, pp. 108-126. Klumer Academic/Plenum Publishers, New York.

Vosmaer, G.C.J. - 1894. Preliminary notes on some tetractinellids of the Bay of Naples. Tijdschr. Nederl. Dierk. Ver., 2(4): 269-286.

Wilson, H.V. - 1925. Siliceous and horny sponges collected by the U.S. Fisheries Steamer "Albatross" during the Philippine Expedition, 1907-10. U.S. Natn. Mus. Bull., 100, 2(4): i-vii, 273-532.

Scient. ed.: M.J. Uriz.

Received June 21, 2010. Accepted January 11, 2011.

Published online April 25, 2011 